\title{
OČEKIVANJA UČENIKA OD OBRAZOVANJA U GLAZBENOJ ŠKOLI
}

Članak prikazuje istraživanje očekivanja učenika od glazbenog obrazovanja u glazbenoj školi provedeno u okviru aktivnosti obilježavanja 190 godina od početka rada Glazbene škole u Varaždinu. Rezultati pokazuju da su učenici u velikoj mjeri zadovoljni glazbenim obrazovanjem, a njihova očekivanja ostvarena. Tijekom srednje škole učenici upoznaju tek dio obrazovnih, pa zatim i profesionalnih mogućnosti u glazbi. Njihove bi vidike glazbena škola u budućem radu trebala dodatno proširiti.

\section{UVOD: ŠKOLA U 21. STOLJEĆU - IZMEĐU TRADICIONALNE I SUVREMENE OBRAZOVNE PARADIGME}

Isticanje velikih, brzih i nepredvidivih gospodarskih i društvenih promjena koje se događaju na globalnoj razini, posljednjih je desetljeća na razne načine sveprisutno u različitim medijima kako popularnim ${ }^{1}$ tako i znanstvenim. ${ }^{2}$ Stvaranjem dominantne slike o važnosti, nužnosti, neizbježnosti i nezaustavljivosti tih,

1 Usp. Dejan LJUŠTINA, „Svijet i Hrvatska, trendovi koji će obilježiti 2017.", Jutarnji list, 29. siječnja 2017., https://www.jutarnji.hr/vijesti/svijet/svijet-i-hrvatska-trendovi-koji-ce-obiljeziti-2017/5562695/, 08.01. 2018.; Gordana POPOVIĆ, Susreti s učenicima u srednjim školama: priručnik za razrednike, Đakovo: Tempo, 2008.

2 Usp. Davor BRĐANOVIĆ, „Glazba u 21. stoljeću - između dokolice i kiča“, Nova prisutnost, 11 (1), Zagreb, 2013., 89-100; France VREG, „Globalizacija in elektronska demokracija: Politološko-sociološki vidiki razvoja informacijske družbe", Teorija in praksa, 38 (1), Ljubljana, 2001., 5-28. 
sadašnjih i budućih promjena, potreba njihovog kritičkog promišljanja stavlja se u drugi plan, pa takav pristup naglašava i favorizira samo „jednu stranu medalje“. Naime, s jedne strane izvjesno je kako su promjene konstanta ljudskog društva dok, s druge strane, one zasigurno nisu ni njegov jedini ni glavni sadržaj i smisao.

$U$ aktualnom globalnom kontekstu u kojem se globalizacija predstavlja „poput neke prirodne sile“ uz bezrezervno „uvjeravanje u neophodnost prilagodbe uvjetima tržišta“, 3 obrazovanje se nalazi u procjepu između proturječnih očekivanja koja društvo na njega projicira - istovremenih očekivanja kontinuiteta i promjena. $^{4}$

Ovdje je potrebno nešto reći o samom pojmu obrazovanje. Njegovu današnju upotrebu Pastuović pojašnjava na slijedeći način: „Edukacija je pohrvaćeni internacionalizam koji obuhvaća i obrazovanje i odgoj. Kada se edukacija želi zamijeniti jednom hrvatskom riječju, onda se u općoj javnosti, zakonodavstvu i akademskoj javnosti (osim u pedagogiji) prednost daje obrazovanju, a ne odgoju. Terminološka prednost obrazovanja kao višeg rodnog pojma pred odgojem je u tome što obrazovati znači formirati obraz (osobnost), a uključuje kognitivno, afektivno i motivativno područje ličnosti. Terminološka prednost obrazovanja nad odgojem kao širim pojmom proizlazi i iz toga što je edukacija (osim predškolske edukacije), kao cjeloživotni proces, u većoj mjeri ispunjena obrazovnom nego odgojnom komponentom. Zbog toga ćemo i mi kao hrvatsku istoznačnicu edukacije rabiti naziv obrazovanje, a odgoj samo onda kada njime želimo označiti organizirano afektivno učenje (organizirano učenje vrijednosti, stavova i navika). ${ }^{\prime 5}$

Slijedeći takvo tumačenje u ovom, kao i u dosadašnjim autorovim radovima, termin obrazovanje (edukacija) podrazumijeva i obrazovanje i odgoj koji se ostvaruju u školi.

Dok se od škole u dijelu koji se odnosi na njezine odgojne komponente dijelom i traži kontinuitet, jer „na vrednotama prošlosti odgajamo za budućnost“, 6

3 Anita BUŠLJETA, „Globalizam - ideologija globalizacije“, Socijalna ekologija: časopis za ekološku misao i sociologijska istraživanja okoline, 19 (2), Zagreb, 2010., 127-149 (str. 137).

4 Usp. Louise STOLL i Dean FINK, Mijenjajmo naše škole: kako unaprijediti djelotvornost i kvalitetu škola, Zagreb: Educa, 2000.

5 Nikola PASTUOVIĆ, Obrazovanje i razvoj: Kako obrazovanje razvija ljude i mijenja društvo, a kako društvo djeluje na obrazovanje, Zagreb: Institut za društvena istraživanja u Zagrebu i Učiteljski fakultet Sveučilišta u Zagrebu, 2012., 25-26.

6 Stjepan CIPEK, „Pedagoška važnost susreta u odgojno-obrazovnom procesu“, Učenici, učitelji i roditelji zajedno na putu uspješnog odgoja i obrazovanja: suradnja, partnerstvo, međuljudski odnosi, međusobno povjerenje i poštovanje, suodgovornost, Zbornik radova 7. učiteljske škole održane 10. - 12. studenog 2005. godine u Lovranu, Hrvatski pedagoško književni zbor, gl. ur. Hrvoje VRGOČ, Zagreb, 2005., 95-106. (str. 97). 
među primarnim očekivanjima od obrazovanih komponenti škole - razvijanje je kompetencija potrebnih za rad. To pred nju postavlja ne samo nužnost stalnih prilagodbi trenutnim zahtjevima tržišta rada već i nužnost predviđanja onih budućih. Škola dakle, kako bi opravdala očekivanja, treba svoje učenike učiniti tržišno konkurentnim i lako zapošljivim. Kao spasonosno rješenje u ostvarivanju navedenih ciljeva - čija je realističnost vrlo upitna i koji u konačnici dovode do dehumanizirajućeg pretvaranja učenika, budućih radnika, u robu na tržištu rada - provode se različite obrazovne reforme. No, iskustva pokazuju kako reforme najčešće završavaju neuspjehom, ${ }^{7}$ a jedan od razloga njihovog neuspjeha zasigurno je i to što se, kako je vidljivo iz prakse, u njima gotovo u pravilu najmanje pažnje posvećuje obrazovnim očekivanjima onih koje se obrazovanje najviše tiče - a to su učenici.

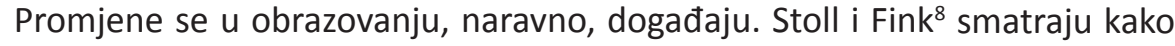
su se učitelji, nastavnici i škole u velikom broju zapadnih zemalja s „vremenom uvelike promijenili“ i prilagodili svoj rad društvenim zahtjevima - u čemu reforme nisu odigrale neku ulogu. Istovremeno, „grupiranje po dobi i sposobnostima, odvojeni nastavni predmeti, srednjoškolska usmjerenja i izolirane učionice ${ }^{\text {" }}$ kao tradicionalne karakteristike škole i dalje u njoj prevladavaju.

\section{OČEKIVANJA OD OBRAZOVANJA I U OBRAZOVANJU}

Osim društva, napose gospodarstva i politike koji od obrazovanja i škole promatrajući ih općenito kao sinonime - očekuju kvalitetu, demokratičnost, humanost i uspješnost ${ }^{10}$, od obrazovanja svoja očekivanja imaju i svi ostali njegovi dionici: učenici, roditelji, nastavnici - pedagozi praktičari i fakulteti koji ih obrazuju, znanstvenici čiji je obrazovanje interes pa i sama škola.

7 Usp. Antun MIJATOVIĆ, „Usustavljivanje razvoja obrazovanja“, Društvena istraživanja, 5 (1) 21, Zagreb, 1996., 3-22.; Neven SESARDIĆ, „Fatamorgana obrazovne reforme“, Jutarnji list, 7. siječnja 2018., https://www.jutarnji.hr/vijesti/obrazovanje/fatamorgana-obrazovne-reforme-ugledni-hrvatski-filozof-propitkuje-dosege-ulaganja-u-unapredenje-skolskog-sustava/6906738/, 08.01.2018.; Neven SESARDIĆ, „Zašto je, ipak, racionalno smanjiti očekivanja od obrazovne reforme?", Jutarnji list, 20. siječnja 2018., https://www.jutarnji.hr/magazin/zasto-je-ipak-racionalno-smanjiti-ocekivanja-od-obra zovne-reforme-ugledni-filozof-odgovara-na-kritike-koje-je-dobio-zbog-svoje-provokacije/6952269/, 21.01.2018.

8 Louise STOLL i Dean FINK, Mijenjajmo naše škole: kako unaprijediti djelotvornost i kvalitetu škola, Zagreb: Educa, 2000., 26.

9 Isto, 26.

10 Usp. Slavko VUČAK, „Prema školi koja uči: zajednici učenika, učitelja i roditelja“, Učenici, učitelji $i$ roditelji zajedno na putu uspješnog odgoja i obrazovanja: suradnja, partnerstvo, međuljudski odnosi, međusobno povjerenje i poštovanje, suodgovornost, Zbornik radova 7. učiteljske škole održane 10. - 12. studenog 2005. godine u Lovranu, Hrvatski pedagoško književni zbor, gl. ur. Hrvoje VRGOČ, Zagreb, 2005., 37-49. 
Raspravljajući o djelotvornosti škole i podizanju kvalitete školskih rezultata u realizaciji obrazovnih ciljeva, definirajući njezine zadatke sa znanstvenog polazišta, Stoll i Fink ${ }^{11}$ od djelotvorne i kvalitetne škole očekuju da:

- „promiče napredak svih učenika povrh onoga što bi se moglo očekivati s obzirom na početni uspjeh i pozadinske čimbenike,

- omogućuje da svi učenici postižu najviše moguće standarde,

- poboljšava sve aspekte učeničkog uspjeha i razvoja,

- poboljšava svoju kvalitetu iz godine u godinu. ${ }^{\text {- } 12}$

Sasvim je jasno kako se kvalitetno obrazovanje u školi ne može ostvariti bez kvalitetnih i motiviranih nastavnika ${ }^{13}$. Važan korak u osiguravanju te kvalitete privlačenje je kvalitetnih studenata na učiteljske i nastavničke fakultete. No, bez šireg društvenog dogovora i akcije podizanja ugleda i poželjnosti nastavničke profesije, pitanje je koliko je realno očekivati da će se to dogoditi.

Stvaranje suradničkog umjesto antagonističkog ozračja u razredu, ${ }^{14}$ važno je pedagoško očekivanje od škole - barem na deklarativnoj razini. Međutim, prevladavajući sustav vrednovanja i ocjenjivanja ${ }^{15}$ predstavlja značajnu prepreku ostvarivanju tog cilja jer potiče natjecanje nauštrb suradnje.

Gledajući očekivanja današnje škole kao organizacije, točnije rečeno očekivanja njezinog menadžmenta, Resman smatra kako ona idu u smjeru:

- razvijanja kvalitetnog timskog rada i timske kulture nastavnika,

- uključivanja učitelja i drugih zaposlenika škole, roditelja, lokalne zajednice i učenika u donošenje odluka te

- motiviranja učenika i učitelja na kvalitetnu suradnju,

- dakle u smjeru razvoja ukupnog „sudjelovanja“ svih protagonista u školi ${ }^{16}$.

11 Usp. Louise STOLL i Dean FINK, Mijenjajmo naše škole: kako unaprijediti djelotvornost $i$ kvalitetu škola, Zagreb: Educa, 2000.

12 Louise STOLL i Dean FINK, Mijenjajmo naše škole: kako unaprijediti djelotvornost i kvalitetu škola, Zagreb: Educa, 2000., 51.

13 Usp. Nikola PASTUOVIĆ, Obrazovanje i razvoj: Kako obrazovanje razvija ljude i mijenja društvo, a kako društvo djeluje na obrazovanje, Zagreb: Institut za društvena istraživanja u Zagrebu i Učiteljski fakultet Sveučilišta u Zagrebu, 2012.

14 Usp. Paola DI PIETRO, Kako preživjeti djetetovu školu, Rijeka: Izdavački centar Rijeka, 2009.

15 Usp. Davor BRĐANOVIĆ, „Vrednovanje u glazbenom obrazovanju i obrazovna reforma: stavovi nastavnika glazbene škole prema godišnjem ispitu sviranja instrumenta", Napredak: časopis za pedagogijsku teoriju i praksu, 158 (3), Zagreb, 2017., 339 - 362.

16 Metod RESMAN, „Timska kultura - oporba razrednoj kulturi“, Učenici, učitelji i roditelji zajedno na putu uspješnog odgoja i obrazovanja: suradnja, partnerstvo, međuljudski odnosi, međusobno po- 
Kada se govori o očekivanjima roditelja od škole, primjerice na području međusobne suradnje, istraživanja pokazuju kako se ona prvenstveno odnose na dobru informiranost o ocjenama, na laku dostupnost učitelja i aktivno sudjelovanje u donošenju odluka - ponajviše o izletima ili o potrebnim obrazovnim postignućima učenika. ${ }^{17}$ Roditeljska pak očekivanja od djece prvenstveno se svode na uspjeh u školi i dobre ocjene ${ }^{18}$ te stjecanje konkretnih i iskoristivih kompetencija za budući život i rad.

Stjecanje novih i korisnih znanja i vještina, zanimljivi nastavni sadržaji, poticajni nastavnici te druženje i upoznavanje novih prijatelja najčešća su očekivanja učenika od škole. U određenoj mjeri kod njih je prisutno i očekivanje kvalitete pretpostavke uspjeha u obrazovanju i vezano uz nju - očekivanje uspjeha, premda se čini kako ta očekivanja tijekom školovanja slabe.

Naime, većina učenika na početku svog školskog puta želi dobro i kvalitetno raditi i učiti. ${ }^{19} \mathrm{~S}$ vremenom dolazi do promjene pa kada se učenike srednje škole pita o njihovim očekivanjima od škole vezanim uz kvalitetu, većina kvalitetu vidi u sportskim, glazbenim i glumačkim aktivnostima te u što boljem ukupnom školskom uspjehu koji im je važan za nastavak školovanja. Međutim, „gotovo je nitko ne nalazi u redovitoj nastavi“ i gotovo „svi priznaju da nikad nisu kvalitetno radili i ni ne namjeravaju“20. Između učenja za ocjenu i kvalitetnog rada učenici - barem oni koje je anketirao Glasser ${ }^{21}$ - očito ne stavljaju znak jednakosti.

Slično se događa i s očekivanjem uspjeha u školi. Na početku školovanja svi učenici žele i očekuju uspjeh, teže znanju ${ }^{22}$ i smatraju se kreativnima, ${ }^{23}$ ali kod većine to s vremenom slabi ili čak potpuno nestaje. ${ }^{24}$ Pritom je važno reći kako se u zaustavljanju ili čak sprečavanju pojave opisanih negativnih trendova

vjerenje i poštovanje, suodgovornost, Zbornik radova 7. učiteljske škole održane 10. - 12. studenog 2005. godine u Lovranu, Hrvatski pedagoško književni zbor, gl. ur. Hrvoje VRGOČ, Zagreb, 2005., 1335 (str. 16).

17 Usp. Željko BURCAR, „Što roditelji očekuju od škole kada ih se pozove na suradnju“, Učenici, učitelji i roditelji zajedno na putu uspješnog odgoja i obrazovanja: suradnja, partnerstvo, međuljudski odnosi, međusobno povjerenje i poštovanje, suodgovornost, Zbornik radova 7. učiteljske škole održane 10. - 12. studenog 2005. godine u Lovranu, Hrvatski pedagoško književni zbor, gl. ur. Hrvoje VRGOČ, Zagreb, 2005., 118-122.

18 Usp. Paola DI PIETRO, Kako preživjeti djetetovu školu, Rijeka: Izdavački centar Rijeka, 2009.

19 Usp. William GLASSER, Kvalitetna škola: škola bez prisile, Zagreb: Educa, 1994.

20 William GLASSER, Kvalitetna škola: škola bez prisile, Zagreb: Educa, 1994., 13.

21 Usp. William GLASSER, Kvalitetna škola: škola bez prisile, Zagreb: Educa, 1994.

22 Usp. Ellen KEY, Stoljeće djeteta, Zagreb, Educa, 2000.

23 Usp. Ken ROBINSON i Lou ARONICA, Element, Zagreb. V.B.Z. d.o.o., 2011.

24 Usp. Ellen KEY, Stoljeće djeteta, Zagreb: Educa, 2000.; Ken ROBINSON i Lou ARONICA, Element, Zagreb: V.B.Z. d.o.o., 2011. 
značajnim pokazuju visoka očekivanja nastavnika od učenika, pogotovo u nižim razredima, ${ }^{25}$ kao i njihova dobra međusobna interakcija - komunikacija, poštovanje, povjerenje i suradnja tijekom cijelog školovanja. ${ }^{26}$

Očigledno, obrazovna očekivanja od kojih je prethodno u tekstu naveden samo dio - brojna su, raznolika i promjenjiva. Među njima, znanstveni interes ovog rada usmjeren je specifičnostima obrazovnih očekivanja učenika na umjetničkom području - istraživanju očekivanja učenika od obrazovanja u glazbenoj školi.

\section{OBRAZOVNA OČEKIVANJA OD GLAZBENOG OBRAZOVANJA U GLAZBENOJ ŠKOLI}

Glazbeno obrazovanje u glazbenoj školi, posebno nastava sviranja glazbenog instrumenta koja se zbog svoje specifične prirode odvija u optimalnoj ravnoteži tradicionalnih i suvremenih obrazovnih postupaka - dobar je primjer uspješnog suživota „starog“ i „novog“ u obrazovanju. Poučavanjem sviranja, koje je i danas zasnovano na odnosu šegrt-učenik i majstor-nastavnik, učenicima se prenose znanja o glazbi napisanoj prije pedeset, stotinu pa i više godina. Učenjem o vremenu u kojem su pojedine skladbe nastale i o načinu njihovog izvođenja - od tehničkih do interpretativno umjetničkih vještina, ${ }^{27}$ prenosi se glazbeno-pedagoška tradicija i povijesno iskustvo te razvija sviračka kompetencija. S druge strane, u suvremenom glazbenom kontekstu obrazovna nužnost glazbenog obrazovanja, kao što bi to uostalom na odgovarajući način trebala biti nužnost i ostalih obrazovnih područja - kontinuirano je prilagođavanje novim pedagoškoglazbeno-znanstveno-tehnološko-umjetničkim spoznajama, zahtjevima i kompetencijskim izazovima.

Očekivanja od glazbenog obrazovanja u glazbenoj školi - i kao subjektivna, odnosno osobna očekivanja učenika koja zanimaju ovaj rad i kao društvena očekivanja - prvenstveno su usmjerena ostvarivanju dva glazbeno-pedagoška cilja. Jedan je cilj glazbeno opismenjavanje što većeg broja djece, razbijanje stereo-

25 Usp. Robert ROSENTHAL i Lenore JACOBSON, „Pygmalion in the Classroom“, The Urban Review, 3 (1), Dordrecht, 1968., 16-20.

26 Usp. Slavica ŠıMIĆ ŠAŠıć, „Odnos nastavnik - učenik: sličnosti i razlike s obzirom na dob učenika te efekti na učenje“, Odnosi u školi: prilozi za pedagogiju odnosa, Monografija, Učiteljski fakultet Sveučilišta u Zagrebu, ur. Vesna BILIĆ i Slavica BAŠIĆ, Zagreb, 2016., 98-133.

27 Usp. Davor BRĐANOVIĆ, Glazbene sposobnosti, osobine ličnosti i obilježja okoline kao prognostički pokazatelji razvoja glazbene kompetencije, Doktorska disertacija, Zagreb: Sveučilište u Zagrebu, Učiteljski fakultet, 2016. 
tipa o glazbi - naročito klasičnoj te promoviranje kvalitetne glazbe, ${ }^{28}$ odnosno „sustavno podizanje glazbene naobrazbe u populaciji putem odgajanja ljubitelja glazbe - glazbene publike te budućih glazbenika amatera.“ ${ }^{29}$ Drugi je cilj „rano identificiranje iznimno glazbeno nadarene djece i njihovo uključivanje u programe primjerene takvim natprosječnim sposobnostima"30 na osnovnoškolskoj, a zatim i na srednjoškolskoj razini te razvoj budućih glazbenih profesionalaca i umjetnika.

Pojam očekivanje u psihologiji se tumači kao „hipotetičko stanje organizma, vrsta stava ili seta, ${ }^{31}$ koje je izraz iskustvom oblikovanog predviđanja da će se nešto dogoditi; bihevioristi ga shvaćaju kao stanje povećane pripravnosti na reagiranje; u suvremenim kognitivnim teorijama (npr. motivacije) shvaća se kao subjektivno uvjerenje u vezi s ishodom nekog događaja i određuje se fenomenološki, na temelju subjektivnih procjena vjerojatnosti pojedinih ishoda." ${ }^{\text {"32 }}$

Različite teorije očekivanja temelj imaju u vjerojatnosti ostvarivanja zacrtanih ciljeva i vrijednosti tih ciljeva za pojedinca. ${ }^{33}$ Atkinson smatra kako na očekivanja s jedne strane utjecaj ima potreba za uspjehom: motivacija za uspjeh, procijenjena vjerojatnost uspjeha i poticajna vrijednost mogućeg uspjeha. $\mathrm{S}$ druge strane očekivanja oblikuje i potreba za izbjegavanjem neuspjeha putem: motiva za izbjegavanje neuspjeha, procjene vjerojatnosti neuspjeha i negativne poticajne vrijednosti neuspjeha. ${ }^{34}$ Zato „Ijudi imaju sklonost realistično mijenjati svoje ciljeve (odnosno svoja očekivanja njihovog ostvarivanja ${ }^{35}$ ) u skladu s prošlim iskustvom."36

Kod svih učenika, a tu nisu izuzetak i učenici glazbene škole, preferencije, ${ }^{37}$ postavljeni ciljevi i razina očekivanja njihove realizacije snažno ovise o okolini

28 Usp. Davor BRĐANOVIĆ, „Glazbena darovitost i obrazovni sustav“, Školski vjesnik: časopis za pedagoška i školska pitanja, 64 (4), Split, 2015., 661-678.

29 Davor BRĐANOVIĆ, „Glazbena darovitost i obrazovni sustav“, Školski vjesnik: časopis za pedagoška i školska pitanja, 64 (4), Split, 2015., 661-678, (str. 673).

30 Isto, 673.

31 Mentalno i/ili emocionalno stanje usmjereno prema nekom podražaju (op. aut.).

32 Boris PETZ (ur.), Ivan FURLAN, Slavko KLJAJIĆ, Vladimir KOLESARIĆ, Mirjana KRIZMANIĆ, Silvija SZABO i Branimir ŠVERKO, Psihologijski rječnik, Jastrebarsko: Naklada Slap, 2005., 307.

33 Usp. Robert C. BECK, Motivacija: teorija i načela, Jastrebarsko: Naklada Slap, 2003.

34 Usp. isto.

35 Op. aut.

36 Lewin i sur., prema Robert C. BECK, Motivacija: teorija i načela, Jastrebarsko, Naklada Slap, 2003., 325.

37 Usp. Davor BRĐANOVIĆ, „Glazbene preferencije učenika srednje glazbene škole“, Napredak: časopis za pedagogijsku teoriju i praksu, 155 (1-2), Zagreb, 2014., 47-64. 
- pogotovo o nastavnicima, roditeljima, vršnjacima i kulturi u kojoj se glazba poučava, što „ima veliku ulogu u procesu glazbenih aktivnosti“" ${ }^{138}$ te glazbenom obrazovanju i razvoju glazbene kompetencije učenika. U tom kontinuiranom međudjelovanju dragocjenu pomoć pri planiranju nužnih obrazovnih promjena pružaju rezultati različitih istraživanja aktualnih učeničkih očekivanja, pa tako i njihovih očekivanja od glazbenog obrazovanja.

\section{CILJ I HIPOTEZE ISTRAŽIVANJA}

Kao dio aktivnosti povodom 190. godišnjice početka rada Glazbene škole u Varaždinu, ovo je istraživanje zamišljeno i provedeno kao svojevrstan znanstveni doprinos obilježavanju tog jubileja. Shvaćajući važnost gotovo dvostoljetne prisutnosti i djelovanja Škole na hrvatskoj pedagoško-glazbenoj sceni, rad polazi od današnjih učenika i njihovih stavova smatrajući ih važnim odrednicama planiranja razvoja Škole za vrijeme koje dolazi. Svojim znanstvenim interesom članak je usmjeren raspravi obrazovnih karakteristika glazbenog obrazovanja u glazbenoj školi, propitivanju učeničkih očekivanja od glazbene škole i glazbenog obrazovanja te traženju odgovora na pitanje kako suvremeno glazbeno obrazovanje vide učenici.

Dakle, osnovni je cilj ovog rada istražiti očekivanja učenika glazbene škole od glazbenog obrazovanja u glazbenoj školi. Namjera je pokazati postoje li razlike u promatranim stavovima učenika, odnosno njihovim očekivanjima prema glazbenom obrazovanju s obzirom na spol i dob (razred glazbene škole koji pohađaju). Također, radom se želi utvrditi ostvaruje li glazbena škola glazbeno-obrazovna očekivanja učenika. Stoga su na početku istraživanja postavljene slijedeće hipoteze:

H1: Između učenika i učenica postoje razlike u očekivanjima prema glazbenom obrazovanju u glazbenoj školi.

H2: S obzirom na njihovu dob - razred glazbene škole koji polaze, postoje razlike u očekivanjima učenika prema glazbenom obrazovanju u glazbenoj školi.

H3: Glazbena škola ostvaruje glazbeno-obrazovna očekivanja učenika.

\section{Uzorak i metoda}

U istraživanju, koje je bilo dobrovoljno i anonimno, sudjelovala su 152 učenika Glazbene škole u Varaždinu (Tablica 1).

38 Tanja ALAČ, „Utjecaj okolinskih faktora na motivaciju učenika glazbene škole“, Tonovi, 58 (2), Zagreb, 2011., 42-76 (str. 44). 
Tablica 1. Ispitanici u istraživanju

\begin{tabular}{|c|c|c|c|}
\hline Ispitanici & $\mathrm{N}$ & Učenici & Učenice \\
\hline Ukupno & 152 & 74 & 78 \\
\hline
\end{tabular}

i to učenici pripremnih razreda za srednju glazbenu školu te svih razreda srednje glazbene škole (Tablica 2),

Tablica 2. Ispitanici grupirani prema razredima

\begin{tabular}{|l|c|c|c|}
\hline Ispitanici - grupe & $\begin{array}{c}\text { 1. i 2. pripremni } \\
\text { razred za sgš }\end{array}$ & 1. i 2. razred sgš & 3. i 4. razred sgš \\
\hline Ukupno & 35 & 62 & 55 \\
\hline
\end{tabular}

prosječne dobi 16,67 godina (Tablica 3).

Tablica 3. Dob ispitanika

\begin{tabular}{|l|c|c|c|c|}
\hline & N & Mean & Min. & Max. \\
\hline Ispitanici - dob & 152 & 16,67 & 12,50 & 21,75 \\
\hline
\end{tabular}

$U$ istraživanje su uključeni oni učenici koji su se u trenutku njegovog provođenja nalazili na nastavi i za koje je pribavljena suglasnost za sudjelovanje. Može se reći da, iako prigodan, uzorak dobro predstavlja promatranu populaciju s obzirom na to da anketirani učenici čine gotovo $69 \%$ od ukupnog broja učenika Škole - u trenutku provedbe istraživanja pripremne razrede i srednju glazbenu školu u Varaždinu pohađao je ukupno 221 učenik.

Pored pitanja o spolu i dobi učenika, Upitnik glazbenih očekivanja konstruiran za ovo istraživanje sastojao se od osamnaest pitanja/tvrdnji o očekivanjima učenika od glazbenog obrazovanja sa skalama procjene Likertova tipa s pet stupnjeva procjene: 1 = uopće se ne slažem s tvrdnjom; 2 = uglavnom se ne slažem $\mathrm{s}$ tvrdnjom; 3 = niti se slažem niti se ne slažem; 4 = uglavnom se slažem s tvrdnjom; 5 = u potpunosti se slažem s tvrdnjom.

Drugi dio upitnika sadržavao je dva pitanja otvorenog tipa. U prvom se od ispitanika tražilo da malo detaljnije opišu svoja sadašnja očekivanja i planove vezane za nastavak glazbenog obrazovanja. Drugim je pitanjem propitano zadovoljstvo učenika trenutnim načinom glazbenog obrazovanja: je li glazbena škola ispunila njihova očekivanja, odnosno koja poboljšanja vide potrebnima pa predlažu njihovo uvođenje. 
U prikazu i obradi dobivenih rezultata upotrijebljeni su standardni statistički postupci: frekvencija podataka, postotak, aritmetička sredina, t-test te KruskalWallisov test. Korišten je statistički program PSPP koji je slobodno dostupan na internetu.

\section{REZULTATI ISTRAŽIVANJA}

U prikazu rezultata dobivenih na skalama procjene (Tablica 4) dane su čestine i postoci slaganja ispitanika sa svakom pojedinom tvrdnjom prvog dijela korištenog anketnog upitnika.

Tablica 4. Čestine i postoci slaganja ispitanika s tvrdnjama upitnika ${ }^{39}$

\begin{tabular}{|c|c|c|c|c|c|c|c|}
\hline $\mathrm{Br}$. & Tvrdnja & $\mathbf{N}$ & $\begin{array}{l}\text { uopće se ne } \\
\text { slažem (1) }\end{array}$ & $\begin{array}{l}\text { uglavnom } \\
\text { se ne } \\
\text { slažem (2) }\end{array}$ & $\begin{array}{l}\text { niti se sla- } \\
\text { žem niti se } \\
\text { ne slažem } \\
\text { (3) }\end{array}$ & $\begin{array}{l}\text { uglavnom } \\
\text { se slažem } \\
\text { (4) }\end{array}$ & $\begin{array}{l}\text { u potpu- } \\
\text { nosti se } \\
\text { slažem (5) }\end{array}$ \\
\hline 1. & Upis gš potakli roditelji & 152 & $60(39,47 \%)$ & $32(21,05 \%)$ & $27(17,76 \%)$ & $24(15,79 \%)$ & $9(5,92 \%)$ \\
\hline 2. & Puno rada-iznenađenje & 152 & $75(49,34 \%)$ & $41(26,97 \%)$ & $19(12,50 \%)$ & $13(8,55 \%)$ & $4(2,63 \%)$ \\
\hline 3. & Želim biti profi glazbenik & 152 & $6(3,95 \%)$ & $9(5,92 \%)$ & $24(15,79 \%)$ & $23(15,13 \%)$ & $90(59,21 \%)$ \\
\hline 4. & Gš nije ispunila očekiv. & 152 & $79(51,97 \%)$ & $41(26,97 \%)$ & $20(13,16 \%)$ & $10(6,58 \%)$ & $2(1,32 \%)$ \\
\hline 5. & Glazba-dobra zarada & 152 & $61(40,13 \%)$ & $31(20,39 \%)$ & $36(23,68 \%)$ & $17(11,18 \%)$ & $7(4,61 \%)$ \\
\hline 6. & Svirati-pjevati nije teško & 152 & $76(50,00 \%)$ & $26(17,11 \%)$ & $40(26,32 \%)$ & $10(6,58 \%)$ & - \\
\hline 7. & U gš treba više prakse & 152 & $15(9,87 \%)$ & $18(11,84 \%)$ & $42(27,63 \%)$ & $41(26,97 \%)$ & $36(23,68 \%)$ \\
\hline 8. & Rezultat u gš nije važan & 152 & $120(78,95 \%)$ & $25(16,45 \%)$ & $4(2,63 \%)$ & $2(1,32 \%)$ & $1(0,66 \%)$ \\
\hline 9. & Glazb. lako nalaze posao & 152 & $16(10,53 \%)$ & $20(13,16 \%)$ & $87(57,24 \%)$ & $25(16,45 \%)$ & $4(2,63 \%)$ \\
\hline 10. & Očekivao sam više popa & 152 & $47(30,92 \%)$ & $32(21,05 \%)$ & $35(23,03 \%)$ & $29(19,08 \%)$ & $9(5,92 \%)$ \\
\hline 11. & Postat ću poznati glazb. & 152 & $19(12,50 \%)$ & $19(12,50 \%)$ & $54(35,53 \%)$ & $26(17,11 \%)$ & $34(22,37 \%)$ \\
\hline 12. & Glazba nudi nastupe & 152 & $5(3,29 \%)$ & $16(10,53 \%)$ & $25(16,45 \%)$ & $55(36,18 \%)$ & $51(33,55 \%)$ \\
\hline 13. & U gš je premalo teorije & 152 & $46(30,26 \%)$ & $42(27,63 \%)$ & $42(27,63 \%)$ & $13(8,55 \%)$ & $9(5,92 \%)$ \\
\hline 14. & Glazba nudi putovanja & 152 & $6(3,95 \%)$ & $13(8,55 \%)$ & $50(32,89 \%)$ & $51(33,55 \%)$ & $32(21,05 \%)$ \\
\hline 15. & Važna je atmosfera u gš & 152 & $1(0,66 \%)$ & $2(1,32 \%)$ & $19(12,50 \%)$ & $35(23,03 \%)$ & $95(62,50 \%)$ \\
\hline 16. & “Cajke” trebaju u kurikul & 152 & $65(42,76 \%)$ & $27(17,76 \%)$ & $42(27,63 \%)$ & $10(6,58 \%)$ & $8(5,26 \%)$ \\
\hline 17. & U gš su najvažnije ocjene & 152 & $20(13,16 \%)$ & $31(20,39 \%)$ & $63(41,45 \%)$ & $27(17,76 \%)$ & $11(7,24 \%)$ \\
\hline 18. & Želim doživotno vježbati & 152 & $2(1,32 \%)$ & $8(5,26 \%)$ & $29(19,08 \%)$ & $39(25,66 \%)$ & 74 (48,68\%) \\
\hline
\end{tabular}

39 U 4. tablici u stupcu Tvrdnja sve tvrdnje upitnika navedene su u skraćenom obliku. Te tvrdnje nalaze se i u tablicama 5, 6 i 7 gdje su napisane u punom obliku - istom koji je korišten u anketnom upitniku $\mathrm{u}$ istraživanju. 
Analizom rezultata u 4. tablici uočava se određeni - ne odveć velik, no ipak zamjetan - postotak anketiranih učenika $(21,71 \%)$ koje su na upis u glazbenu školu potakli roditelji (1. tvrdnja). Premda su time u stvari ispunjena očekivanja roditelja, ova je tvrdnja uvrštena u upitnik kako bi se propitao opseg podudaranja očekivanja i želja učenika i roditelja te uloga roditelja u poticanju i razvoju glazbeno-obrazovnih očekivanja njihove djece. Roditeljska je uloga očito važna kod čak petine anketiranih učenika.

Puno redovitog vježbanja neophodnog za razvoj visoke kompetencijske razine sviranja/pjevanja predstavlja iznenađenje za 11,18\% ispitanika (2. tvrdnja). Zato prije upisa u glazbenu školu svim kandidatima treba temeljito pojasniti specifičnosti i zahtjeve glazbenog obrazovanja kako bi se ovaj postotak, premda relativno nizak, dodatno smanjio. Istovremeno, kod velikog broja ispitanika (74,34\%) postoji očekivanje i izražena želja za cjeloživotnim radom u glazbi - vježbanjem i usavršavanjem vlastitog sviračkog/pjevačkog umijeća (18. tvrdnja). Na potonje se nadovezuju i dobiveni rezultati procjena koji pokazuju da respektabilan broj anketiranih (također 74,34\%) vidi glazbu kao svoju buduću profesiju (3. tvrdnja). Pred školom je stoga odgovornost kvalitetne pripreme učenika za ostvarivanje ovih njihovih očekivanja.

Dobiveni podaci pokazuju nadalje kako glazbena škola nije ispunila očekivanja samo 7,9\% učenika (4. tvrdnja). Taj za školu povoljan podatak dodatno učvršćuju odgovori dobiveni u otvorenim pitanjima upitnika - o čemu nešto kasnije.

Glazbu promatra 15,79\% ispitanika u kontekstu mogućnosti dobre zarade (5. tvrdnja). Dobiveni niski postotak može se, između ostalog, protumačiti time što zarada nije među životnim prioritetima srednjoškolaca. Izvjesno je i da se velik broj učenika glazbom ne bavi zbog mogućnosti zarade nego zbog vlastitog ispunjenja i zadovoljstva koje im glazba pruža, pa im tu ne smeta ni zahtjevnost učenja pjevanja i sviranja koje su svjesni. Naime, sa 6. tvrdnjom, svirati i pjevati nije teško - uglavnom se slaže tek 6,58\% ispitanika dok potpunog slaganja s tom tvrdnjom nema. Vezano uz zaradu u glazbi kod 9. tvrdnje - glazbenici lako nalaze posao - pokazalo se kako učenici glazbene škole nemaju dovoljno informacija o mogućnostima svog kasnijeg zaposlenja. Među svim anketnim pitanjima, u ovom je dobiven najveći broj neutralnih procjena $(57,24 \%$ ispitanika zaokružilo je 3 - niti se slaže niti ne slaže s tvrdnjom). S istom tvrdnjom pritom još $23,69 \%$ anketiranih iskazuje neslaganje. Stoga se može zaključiti kako bi bilo korisno osmisliti školske sadržaje usmjerene upoznavanju učenika s postojećim mogućnostima rada u glazbenim i s glazbom povezanim zanimanjima. U navedeno se objašnjenje uklapa i 11. tvrdnja upitnika gdje se navodi mogućnost aktivnog zaposlenja u glazbi - očekujem da ću postati poznati glazbenik/ca. Dobivena 
raspodjela rezultata nalikuje pravilnoj, a najveći se dio ispitanih $(35,53 \%)$ i ovdje opredijelio za neutralnu procjenu - 3.

Nadalje, nešto više od polovice anketiranih (50,65\%) smatra da glazbena škola treba ponuditi više praktičnih glazbenih sadržaja (7. tvrdnja), dok samo $14,47 \%$ učenika procjenjuje kako u glazbenog školi nedostaje teorijskih glazbenih sadržaja (13. tvrdnja).

S tvrdnjom - nije mi zapravo važno hoću li što naučiti u glazbenoj školi (8. tvrdnja), uopće se ne slaže $78,95 \%$ anketiranih, a $16,45 \%$ se uglavnom ne slaže. Ukupni izraz neslaganja s ovom tvrdnjom ankete $(95,40 \%)$, implicira kako je ogromnoj većini učenika itekako stalo do razvoja vlastitih glazbenih kompetencija. Navedeno odgovarajuće dopunjava i analiza dobivenih procjena kod 17. tvrdnje upitnika - u glazbenoj školi su mi najvažnije ocjene. Najveći se dio ispitanih $(41,45 \%)$ opredijelio za neutralnu procjenu - 3, te raspodjela dobivenih rezultata sliči pravilnoj. Čini se kako u učeničkom sustavu vrijednosti u glazbenoj školi više mjesto zauzima sadržaj i razvoj glazbenih kompetencija od dobrih ocjena.

Zato se ponovo može podcrtati odgovorna zadaća koju škola, u suradnji s ostalim nositeljima obrazovne politike, ima u izboru sadržaja i omogućavanju ostvarivanja učeničkih obrazovnih očekivanja.

Dobiveni rezultati kod 10 . tvrdnje pokazuju da većina učenika $(51,97 \%)$ nije očekivala više sadržaja popularne glazbe u glazbenoj školi. Također, učenici većinom (60,52\%) ne očekuju da novokomponirana „narodna“ glazba uđe u kurikulum glazbene škole (16. tvrdnja).

Velikom broju učenika $(69,73 \%)$ glazbena škola pak omogućava ono što vole - javnu prezentaciju i nastupe (12. tvrdnja) te oni očekuju $(54,60 \%)$ kako će im bavljenje glazbom omogućiti putovanja (14. tvrdnja).

Procjene dobivene od učenika kod 15. tvrdnje upitnika pružaju vrijedan nalaz važan za prepoznavanje glazbene škole kao umjetničke oaze unutar hrvatskog obrazovnog sustava. Naime, 85,53\% ispitanika procjenjuje kako im je važna opuštena umjetnička atmosfera koja karakterizira glazbenu školu (Tablica 4). Kao rezultat toga kod 15. je tvrdnje upitnika dobivena i vrlo visoka prosječna (pr)ocjena - aritmetička sredina svih procjena - od 4,45 (Tablica 5). 
Tablica 5. Dobiveni ukupni rezultati (aritmetičke sredine) u istraživanju

$\mathrm{N}$ - broj ispitanika

Mean (M) - aritmetička sredina

Std. Dev. - standardno odstupanje rezultata od aritmetičke sredine

Min. - minimalni rezultat // Max. - maksimalni dobiveni rezultat (procjena ispitanika)

\begin{tabular}{|c|l|c|c|c|c|c|}
\hline Br. & \multicolumn{1}{|c|}{ Tvrdnja } & $\mathrm{N}$ & Mean & Std. Dev. & Min. & Max. \\
\hline 1. & $\begin{array}{l}\text { Pohađam glazbenu školu jer su me na to } \\
\text { potakli roditelji }\end{array}$ & 152 & 2,28 & 1,29 & 1,00 & 5,00 \\
\hline 2. & $\begin{array}{l}\text { Iznenadilo me što za glazbenu školu treba } \\
\text { redovito dosta vježbati }\end{array}$ & 152 & 1,88 & 1,09 & 1,00 & 5,00 \\
\hline 3. & $\begin{array}{l}\text { Idem u glazbenu školu jer se želim } \\
\text { profesionalno baviti glazbom }\end{array}$ & 152 & $\mathbf{4 , 2 0}$ & 1,15 & 1,00 & 5,00 \\
\hline 4. & Glazbena škola nije ispunila moja očekivanja & 152 & $\mathbf{1 , 7 8}$ & 1,00 & 1,00 & 5,00 \\
\hline 5. & Učim glazbu jer ona omogućava dobru zaradu & 152 & $\mathbf{2 , 2 0}$ & 1,21 & 1,00 & 5,00 \\
\hline 6. & $\begin{array}{l}\text { Upisao/la sam glazbenu školu jer svirati i } \\
\text { pjevati nije teško }\end{array}$ & 152 & $\mathbf{1 , 8 9}$ & 1,01 & 1,00 & 4,00 \\
\hline 7. & $\begin{array}{l}\text { Glazbena škola treba nuditi više praktičnih } \\
\text { glazbenih sadržaja }\end{array}$ & 152 & $\mathbf{3 , 4 3}$ & 1,25 & 1,00 & 5,00 \\
\hline 8. & $\begin{array}{l}\text { Nije mi zapravo važno hoću li što naučiti u } \\
\text { glazbenoj školi }\end{array}$ & 152 & $\mathbf{1 , 2 8}$ & 0,65 & 1,00 & 5,00 \\
\hline 9. & $\begin{array}{l}\text { Kao glazbenik/ca ću lako naći } \\
\text { posao }\end{array}$ & 152 & $\mathbf{2 , 8 8}$ & 0,90 & 1,00 & 5,00 \\
\hline 10. & $\begin{array}{l}\text { U glazbenoj sam školi očekivao/la više nastave } \\
\text { popularne glazbe }\end{array}$ & 152 & $\mathbf{2 , 4 8}$ & 1,27 & 1,00 & 5,00 \\
\hline 11. & Očekujem da ću postati poznati glazbenik/ca & 152 & $\mathbf{3 , 2 4}$ & 1,28 & 1,00 & 5,00 \\
\hline 12. & $\begin{array}{l}\text { Glazba mi omogućava ono što volim - javnu } \\
\text { prezentaciju i nastupe }\end{array}$ & 152 & $\mathbf{3 , 8 6}$ & 1,10 & 1,00 & 5,00 \\
\hline 13. & $\begin{array}{l}\text { U glazbenoj je školi premalo teorijskih } \\
\text { glazbenih sadržaja }\end{array}$ & 152 & $\mathbf{2 , 3 2}$ & 1,17 & 1,00 & 5,00 \\
\hline 14. & $\begin{array}{l}\text { Bavljenje glazbom će mi omogućiti putovanja } \\
\text { po cijelom svijetu }\end{array}$ & 152 & $\mathbf{3 , 5 9}$ & 1,04 & 1,00 & 5,00 \\
\hline 15. & $\begin{array}{l}\text { U glazbenoj školi mi je važna opuštena } \\
\text { umjetnička atmosfera }\end{array}$ & 152 & $\mathbf{4 , 4 5}$ & 0,81 & 1,00 & 5,00 \\
\hline 16. & $\begin{array}{l}\text { Novokomponirana „narodna“ glazba treba biti } \\
\text { u kurikulumu glazbene škole }\end{array}$ & 152 & $\mathbf{2 , 1 4}$ & 1,20 & 1,00 & 5,00 \\
\hline 17. & U glazbenoj školi su mi najvažnije dobre ocjene & 152 & $\mathbf{2 , 8 6}$ & 1,09 & 1,00 & 5,00 \\
\hline 18. & Želim cijeli život vježbati sviranje/pjevanje & 152 & $\mathbf{4 , 1 5}$ & 1,00 & 1,00 & 5,00 \\
\hline
\end{tabular}

Dobivene rezultate istraživanja potrebno je analizirati imajući u vidu obje prethodno prikazane tablice rezultata jer se u njima iskazani podaci međusob- 
no dopunjavaju. Dok prva (Tablica 4) sadrži distribuciju procjena ispitanika na tvrdnjama upitnika, u drugoj (Tablica 5) se nalaze njihove prosječne (pr)ocjene (aritmetičke sredine procjena) za svaku tvrdnju.

Tako, primjerice, rezultati ranije spominjane 1. tvrdnje (Tablica 5) pokazuju relativno nisku prosječnu procjenu ispitanika o ulozi njihovih roditelja u upisu glazbene škole $(M=2,28)$. Međutim, uvidom u čestinu procjena slaganja s 1 . tvrdnjom (Tablica 4) vidljivo je da su roditelji potakli na upis glazbene škole preko $20 \%$ anketiranih - što nije zanemariv postotak. Bez uvida u obje tablice ovaj bi podatak bio neopravdano zanemaren. Na isti je način kod čitanja ovog rada potrebno promotriti sve ostale podatke.

Od dobivenih rezultata (Tablica 5 ) mogu se ovdje još izdvojiti visoka prosječna procjena 4,20 (želim se profesionalno baviti glazbom) i 4,15 (želim cijeli život vježbati) te niska 1,28 (nije mi važno hoću li što naučiti u glazbenoj školi - GŠ) i 1,78 (GŠ nije ispunila moja očekivanja) - koje su u skladu s analizom frekvencija procjena iz prethodne tablice (Tablica 4).

S niskom prosječnom procjenom 1,88 (iznenadilo me što za GŠ treba redovito dosta vježbati) ne treba biti zadovoljan. Premda je ona niska, s obzirom na 19 neodlučnih (niti se slažu niti ne slažu), 13 koji se uglavnom slažu i 4 ispitanika koji se u potpunosti slažu s tvrdnjom ranije izneseni zaključak o potrebni dodatnog informiranja kandidata za upis u glazbenu školu - stoji.

Tablica 6. Dobiveni rezultati t-testa - razlike procjena između učenika i učenica

*razlika je statistički značajna $(t=3,81 ; p=0,000)$

** razlika je vidljiva, ali nije statistički značajna

\begin{tabular}{|l|l|c|c|c|c|c|}
\hline \multirow{2}{*}{ Br. } & \multicolumn{1}{|c|}{ Tvrdnja } & $\begin{array}{c}\text { Spol } \\
\text { ispitanika }\end{array}$ & N & Mean & $\begin{array}{c}\text { Std. } \\
\text { Deviation }\end{array}$ & $\begin{array}{c}\text { S.E. } \\
\text { Mean }\end{array}$ \\
\hline \multirow{2}{*}{ 5. } & $\begin{array}{l}\text { Učim glazbu jer ona omogućava } \\
\text { dobru zaradu }\end{array}$ & muški & 74 & $* 2,57$ & 1,28 & 0,15 \\
\cline { 2 - 7 } & ženski & 78 & $* 1,85$ & 1,03 & 0,12 \\
\hline \multirow{2}{*}{3.} & $\begin{array}{l}\text { Idem u glazbenu školu jer se želim } \\
\text { profesionalno baviti glazbom }\end{array}$ & muški & 74 & $* * 4,36$ & 1,05 & 0,12 \\
\cline { 2 - 7 } & ženski & 78 & $* * 4,04$ & 1,21 & 0,14 \\
\hline \multirow{2}{*}{7.} & $\begin{array}{l}\text { Glazbena škola treba nuditi više } \\
\text { praktičnih glazbenih sadržaja }\end{array}$ & muški & 74 & $* * 3,27$ & 1,23 & 0,14 \\
\cline { 3 - 7 } 11. & $\begin{array}{l}\text { Očekujem da ću postati poznati } \\
\text { glazbenik/ca }\end{array}$ & muški & 78 & $* * 3,58$ & 1,25 & 0,14 \\
\cline { 2 - 7 } & ženski & 78 & $* * 3,05$ & 1,33 & 0,15 \\
\hline
\end{tabular}


Postojanje statistički značajnih razlika u upitnikom propitanim očekivanjima prema glazbenom obrazovanju u glazbenoj školi između učenika i učenica provjereno je u nastavku istraživanja t-testom. Značajna je razlika s obzirom na spol ispitanika nađena kod 5 . tvrdnje. Pokazalo se da učenici statistički značajno više od učenica ( $t=3,81 ; p=0,000)$ procjenjuju kako uče glazbu jer ona omogućava dobru zaradu, što se može tumačiti kulturološki. Kod ostalih tvrdnji upitnika, iako neke razlike postoje (Tablica 6), one nisu pokazale statističku značajnost.

Kruskal-Wallisovim testom provjerile su se zatim razlike u procjenama očekivanja prema glazbenom obrazovanju u glazbenoj školi ispitanika grupiranih s obzirom na njihovu dob - razred glazbene škole koji polaze. Test je pokazao kako statistički značajne razlike postoje kod 1., 2., 3., 4., 5., 6., 7., 13. i 17. tvrdnje (Tablica 7).

Za svaku promatranu grupu ispitanika vrijednosti su u 7. tablici $^{40}$ izražene kao prosječni rang rezultata te grupe. Grupe ispitanika s trendom nižih procjena imaju i niži prosječni rang, dok grupe ispitanika s višim procjenama na tvrdnjama upitnika posljedično imaju i višu brojčanu vrijednost prosječnog ranga. ${ }^{41}$

Pogledaju li se nađene razlike kod primjerice 2. (iznenađenje potrebom vježbanja u GŠ s uzrastom pada), 6. (svijest o zahtjevnosti bavljenja glazbom s uzrastom raste) i 17. tvrdnje upitnika (procjena važnosti ocjena s uzrastom pada) može se ustvrditi kako su te razlike logične, a njihov je smjer - smanjenje procjena s uzrastom - posljedica obrazovanja (utjecaja škole) i razvoja (sazrijevanja) učenika.

Jednako se može reći i za sve ostale nađene statistički značajne razlike procjena očekivanja učenika s obzirom na razred glazbene škole koji polaze. Tako kod 3. (idem u GŠ jer se želim profesionalno baviti glazbom) i 5. tvrdnje (učim glazbu jer ona omogućava dobru zaradu) procjene s uzrastom rastu, kao i kod 7. (GŠ treba nuditi više praktičnih glazbenih sadržaja) te 13. tvrdnje (GŠ ima premalo teorijskih glazbenih sadržaja). Kako sazrijeva odluka o nastavku glazbenog obrazovanja i budućoj karijeri u glazbi u skladu s tim razvijaju se i stavovi učenika.

40 U 7. tablici su navedeni rezultati samo za one tvrdnje korištenog upitnika u istraživanju kod kojih je Kruskal-Wallisov test pokazao statističku značajnost razlika među grupama ispitanika $(p<0,05)$.

41 Usp. Boris PETZ, Vladimir KOLESARIĆ i Dragutin IVANEC, Petzova statistika: Osnovne statističke metode za nematematičare, Jastrebarsko, Slap, 2012. 
Tablica 7. Kruskal-Wallisov test - razlike rezultata grupa ispitanika s obzirom na razred koji polaze

\begin{tabular}{|c|c|c|c|c|c|c|c|}
\hline $\mathrm{Br}$. & Tvrdnja & $\begin{array}{c}\text { Grupa } \\
\text { ispitanika }\end{array}$ & $\mathbf{N}$ & $\begin{array}{c}\text { Mean } \\
\text { Rank }\end{array}$ & Chi-Square & $d f$ & $\begin{array}{l}\text { Asymp. } \\
\text { Signif. }\end{array}$ \\
\hline \multirow{4}{*}{1.} & \multirow{4}{*}{$\begin{array}{l}\text { Pohađam glazbenu školu } \\
\text { jer su me na to potakli } \\
\text { roditelji }\end{array}$} & 1. i 2. pripremni & 35 & 60,93 & \multirow[b]{4}{*}{6,27} & \multirow[b]{4}{*}{2} & \multirow[b]{4}{*}{0,043} \\
\hline & & 1. i 2. sgš & 62 & 80,07 & & & \\
\hline & & 3. i 4. sgš & 55 & 82,38 & & & \\
\hline & & Ukupno & 152 & & & & \\
\hline \multirow{4}{*}{2.} & \multirow{4}{*}{$\begin{array}{l}\text { Iznenadilo me što za } \\
\text { glazbenu školu treba } \\
\text { redovito dosta vježbati } \\
\text { sviranje/pjevanje }\end{array}$} & 1. i 2. pripremni & 35 & 93,51 & \multirow[b]{4}{*}{13,03} & \multirow[b]{4}{*}{2} & \multirow[b]{4}{*}{0,001} \\
\hline & & 1. i 2. sgš & 62 & 79,44 & & & \\
\hline & & 3. i 4. sgš & 55 & 62,36 & & & \\
\hline & & Ukupno & 152 & & & & \\
\hline \multirow{4}{*}{3.} & \multirow{4}{*}{$\begin{array}{l}\text { Idem u glazbenu } \\
\text { školu jer se želim } \\
\text { profesionalno baviti } \\
\text { glazbom }\end{array}$} & 1. i 2. pripremni & 35 & 61,17 & \multirow[b]{4}{*}{7,04} & \multirow[b]{4}{*}{2} & \multirow[b]{4}{*}{0,030} \\
\hline & & 1. i 2. sgš & 62 & 81,48 & & & \\
\hline & & 3. i 4. sgš & 55 & 80,65 & & & \\
\hline & & Ukupno & 152 & & & & \\
\hline \multirow{4}{*}{4.} & \multirow{4}{*}{$\begin{array}{l}\text { Glazbena škola nije } \\
\text { ispunila moja očekivanja }\end{array}$} & 1. i 2. pripremni & 35 & 60,19 & \multirow[b]{4}{*}{11,33} & \multirow[b]{4}{*}{2} & \multirow[b]{4}{*}{0,003} \\
\hline & & 1. i 2. sgš & 62 & 74,48 & & & \\
\hline & & 3. i 4. sgš & 55 & 89,16 & & & \\
\hline & & Ukupno & 152 & & & & \\
\hline \multirow{4}{*}{5.} & \multirow{4}{*}{$\begin{array}{l}\text { Učim glazbu jer ona } \\
\text { omogućava dobru } \\
\text { zaradu }\end{array}$} & 1. i 2. pripremni & 35 & 62,26 & \multirow[b]{4}{*}{6,36} & \multirow[b]{4}{*}{2} & \multirow[b]{4}{*}{0,042} \\
\hline & & 1. i 2. sgš & 62 & 76,85 & & & \\
\hline & & 3. i 4. sgš & 55 & 85,17 & & & \\
\hline & & Ukupno & 152 & & & & \\
\hline \multirow{4}{*}{6.} & \multirow{4}{*}{$\begin{array}{l}\text { Upisao/la sam glazbenu } \\
\text { školu jer svirati i pjevati } \\
\text { nije teško }\end{array}$} & 1. i 2. pripremni & 35 & 94,04 & & & \\
\hline & & 1. i 2. sgš & 62 & 74,06 & & & \\
\hline & & 3. i 4. sgš & 55 & 68,08 & & & \\
\hline & & Ukupno & 152 & & 9,11 & 2 & 0,011 \\
\hline & & 1. i 2. pripremni & 35 & 51,99 & & & \\
\hline & Glazbena skola treba & 1. i 2. sgš & 62 & 80,81 & & & \\
\hline 1. & nualt vise prakticnin & 3. i 4. sgš & 55 & 87,25 & & & \\
\hline & glazbenih sadržaja & Ukupno & 152 & & 15,61 & 2 & 0,000 \\
\hline & & 1. i 2. pripremni & 35 & 55,90 & & & \\
\hline & premalo teoriiskih & 1. i 2. sgš & 62 & 77,27 & & & \\
\hline 13. & premalo teorijskih & 3. i 4. sgš & 55 & 88,74 & & & \\
\hline & glazbenih sadržaja & Ukupno & 152 & & 12,84 & 2 & 0,002 \\
\hline & & 1. i 2. pripremni & 35 & 87,56 & & & \\
\hline 17 & U glazbenoj školi su mi & 1. i 2. sgš & 62 & 81,07 & & & \\
\hline 11. & najvažnije dobre ocjene & 3. i 4. sgš & 55 & 64,31 & & & \\
\hline & & Ukupno & 152 & & 7,78 & 2 & 0,020 \\
\hline
\end{tabular}

Ne treba zaboraviti kako sve dobivene razlike među grupama (Tablica 7), što je ovdje pogotovo važno kod tvrdnji 4 i 13, treba promatrati u svjetlu rani- 
je iznesenih rezultata - većih ili manjih ukupnih procjena ispitanika za pojedinu tvrdnju izraženih aritmetičkim sredinama procjena (Tablica 5). Primjerice, kod 4. tvrdnje upitnika (glazbena škola nije ispunila moja očekivanja) procjene s uzrastom statistički značajno rastu - ali u okviru ukupno vrlo niske procjene - $M=1,78$ (Tablica 5). Ovaj posljednji rezultat otvara prostor za daljnja istraživanja i traženje odgovora na pitanje zašto je to tako - zašto stariji učenici iskazuju niže ostvarenje svojih očekivanja od glazbene škole nego mlađi?

U nastavku ankete u prvom se pitanju otvorenog tipa od ispitanika tražilo da malo detaljnije opišu svoja sadašnja očekivanja i razmišljanja vezana za nastavak glazbenog obrazovanja. Svaki je mogao dati više odgovora/navesti više očekivanja. U tablici (Tablica 8) su pobrojani odgovori koji se u anketama javljaju najmanje tri puta (isti odgovori koji se ponavljaju kod najmanje tri različita učenika). Kao što se može vidjeti, najveći broj ispitanika očekuje kako će se u budućnosti na neki način baviti glazbom profesionalno (180 odgovora), odnosno planira nastaviti pohađati glazbenu školu (121 odgovor) dok samo manji broj učenika očekuje da će mu glazba biti hobi (39 odgovora), tj. ne misli nastaviti svoje glazbeno obrazovanje (24 odgovora).

Tablica 8. Odgovori učenika na prvo pitanje otvorenog tipa

\begin{tabular}{|l|c|}
\hline Sadašnja očekivanja od glazbenog obrazovanja & Broj učenika \\
\hline Planiraju nastaviti pohađati GŠ & 121 \\
\hline Planiraju upisati muzičku akademiju (MA) & 91 \\
\hline U budućnosti žele svirati/pjevati u orkestru/bendu & 39 \\
\hline $\begin{array}{l}\text { Glazba im nije profesionalni prioritet, već draga (buduća) } \\
\text { aktivnost - hobi }\end{array}$ & 39 \\
\hline U budućnosti žele biti nastavnici u području glazbe & 24 \\
\hline Žele kao glazbenici raditi u inozemstvu & 17 \\
\hline Ne planiraju upisati MA & 15 \\
\hline Ne planiraju nastaviti pohađati GŠ & 9 \\
\hline Planiraju upisati MA u inozemstvu & 6 \\
\hline Žele se baviti komponiranjem & 3 \\
\hline
\end{tabular}

Drugim otvorenim pitanjem propitano je zadovoljstvo učenika trenutnim načinom glazbenog obrazovanja - je li glazbena škola ispunila njihova očekivanja i imaju li kakve prijedloge za poboljšanje/moderniziranje nastavnih sadržaja. 
Ranije dobiveni podaci - rezultati procjena za 4. tvrdnju upitnika pokazali su da glazbena škola nije ispunila očekivanja samo 7,9\% učenika (Tablica 4) što podržava i niska prosječna (pr)ocjena od $M=1,78$ iste tvrdnje (Tablica 5). Takav za glazbenu školu dobar podatak dodatno osnažuju odgovori dobiveni u ovom pitanju upitnika. Naime, uz ostale podatke vidljive iz tabele (Tablica 9) koja je formirana prema istom principu kao i prethodna, posebno je uočljivo zadovoljstvo učenika glazbenim obrazovanjem (114 odgovora) koje je ispunilo njihova očekivanja (55 odgovora).

Od ostalih primjedbi česte su još: traženje više izbornosti (26 odgovora), želja za učenjem i druge danas popularne glazbe (19 odgovora), želja za boljom organizacijom nastave/boljim rasporedom (15 odgovora), očekivanje modernizacije kurikuluma, npr. bolje povezivanje teorije s praksom (14 odgovora), nedostatak vremena za bavljenje glazbenim sadržajima zbog puno općeobrazovnih (13 odgovora), premali broj vježbaona u školi (13 odgovora), očekivanje većeg broja glazbenih projekata i nastupa (11 odgovora) itd. (Tablica 9).

Tablica 9. Odgovori učenika na drugo pitanje otvorenog tipa

\begin{tabular}{|l|c|}
\hline Zadovoljstvo glazbenim obrazovanjem/prijedlozi poboljšanja & Broj učenika \\
\hline Zadovoljni su sadašnjim načinom obrazovanja u glazbenoj školi (GŠ) & 96 \\
\hline GŠ je u potpunosti ispunila njihova očekivanja & 43 \\
\hline Uglavnom su zadovoljni načinom obrazovanja u GŠ & 18 \\
\hline GŠ je uglavnom ispunila njihova očekivanja & 12 \\
\hline $\begin{array}{l}\text { Žele više izbornosti: jezici, ples, scena, razne glazbe, produkcija, obrada } \\
\text { tona... }\end{array}$ & 26 \\
\hline Žele učiti i druge danas popularne glazbe & 19 \\
\hline Voljeli bi imati bolju organizaciju nastave/bolji raspored & 15 \\
\hline $\begin{array}{l}\text { Predlažu modernizaciju kurikuluma (npr. bolje povezivanje teorije s } \\
\text { praksom) }\end{array}$ & 14 \\
\hline $\begin{array}{l}\text { Puno je općeobrazovnih - pa nema vremena za bavljenje glazbenim } \\
\text { sadržajima }\end{array}$ & 13 \\
\hline Predlažu osiguravanje više vježbaona u školi & 13 \\
\hline Predlažu povećanje broja glazbenih projekata i nastupa & 11 \\
\hline Ima previše obaveznih predmeta & 11 \\
\hline Predlažu više „terenske“ nastave (odlasci na koncerte, seminare...) & 5 \\
\hline Žele više praktične glazbene nastave & 4 \\
\hline Žele više komornog muziciranja & 4 \\
\hline Predlažu više sati glavnog predmeta & 4 \\
\hline $\begin{array}{l}\text { Žele predmet o instrumentima jer učenici premalo znaju o svom } \\
\text { instrumentu }\end{array}$ & 3 \\
\hline
\end{tabular}




\section{RASPRAVA I ZAKLJUČAK}

Prema dobivenim rezultatima, prva hipoteza ovog istraživanja - kako između učenika i učenica postoje razlike u očekivanjima prema glazbenom obrazovanju u glazbenoj školi - može se gotovo u potpunosti odbaciti. Među 18 tvrdnji upitnika značajna je razlika s obzirom na spol ispitanika nađena, kao što je već rečeno, samo kod jedne - 5. tvrdnje. Pokazalo se da učenici statistički značajno više od učenica procjenjuju kako uče glazbu jer ona omogućava dobru zaradu pri čemu, dodatno, dobivene ukupne procjene s uzrastom rastu. To se može objasniti primjerice time što stariji učenici već imaju različite honorarne angažmane u glazbi pa u njoj vide razne načine za zaradu. Također, objašnjenje se može potražiti i u percepciji neizvjesnosti dobivanja stalnog posla u glazbi koji je učenicama možda i važniji od iznosa same zarade. Pritom je izvjesno kako u takvim „stalnim“ poslovima nije realno očekivati „dobru zaradu“.

Druga hipoteza kako, s obzirom na njihovu dob (razred glazbene škole koji polaze) - postoje razlike u očekivanjima učenika prema glazbenom obrazovanju u glazbenoj školi - može se velikim dijelom prihvatiti. Kod 9 od 18 pitanja anketnog upitnika nađene su i prethodno u tekstu prikazane statistički značajne razlike među grupama konstruiranim prema razredu koji ispitanici polaze. Te su razlike valja ponoviti - logične s obzirom na sazrijevanje i razvoj glazbenih kompetencija obrazovanjem učenika, a važno ih je promatrati u kontekstu ukupnih rezultata istraživanja.

U svjetlu iznesenih nalaza kako glazbena škola nije ispunila očekivanja samo 7,9\% ispitanika i niske prosječne procjene $M=1,78$ kod te tvrdnje, uz 114 učenika koji izrijekom navode svoje zadovoljstvo glazbenim obrazovanjem, treća hipoteza - glazbena škola ostvaruje glazbeno-obrazovna očekivanja učenika - može se prihvatiti. Prostora za poboljšanja, vidljivo je, još uvijek ima.

Provedeno istraživanje pokazalo je kako ne treba zaboraviti da su roditeljska očekivanja važna za razvoj očekivanja njihove djece. Nadalje, učenici ocjenjuju da im je stalo do razvoja vlastitih glazbenih kompetencija, a tu pokazuju i zrelost svjesni potrebe cjeloživotnog rada u glazbi. Izgleda da u sustavu vrijednosti učenika glazbene škole više mjesto zauzima sadržaj i razvoj glazbenih kompetencija od dobrih ocjena čime oni na svoj način odgovaraju na pitanje treba li osnovno očekivanje od obrazovanja i njegov cilj biti uspjeh na testovima, dobre ocjene i završna svjedodžba ili je obrazovni prioritet razvoj samostalnosti, kritičkog mišljenja, prilagodljivosti promjenama te stjecanje praktično iskoristivih kompetencija.

Potreba dodatnog informiranja kandidata o specifičnostima glazbenog obrazovanja prilikom upisa u glazbenu školu također je vidljiva. Izvjesno je i da uče- 
nici nemaju dovoljno spoznaja o obrazovnim i profesionalnim mogućnostima povezanim $\mathrm{s}$ glazbom. $\mathrm{S}$ druge strane sasvim je jasno postojanje velike širine glazbenog i s glazbom povezanog područja. Nije realno očekivati da škola svojim obrazovnim programima obuhvati sve mogućnosti u, i oko glazbe. Stoga je važno usvajanje bazičnih glazbenih znanja, razvoj unutrašnje motivacije, znatiželje, kreativnosti i građenje navika samostalnog rada i istraživanja vlastitih sposobnosti. Važno je da učenici prepoznaju vlastite sposobnosti i odgovarajuće se usmjere razvijanju specifičnih znanja i vještina tražeći svoje mjesto u glazbi. Škola tu treba ponuditi što više informacija o mnogobrojnim i različitim mogućnostima.

Naposlijetku, u doprinosu prepoznavanju glazbene škole kao umjetničke oaze unutar hrvatskog obrazovnog sustava, potrebno je zaključno još jednom naglasiti i ponoviti dobiveni nalaz ovog rada o opuštenoj umjetničkoj atmosferi koja karakterizira glazbenu školu i koja je učenicima glazbene škole važna. Tu "atmosferu“ nikako ne treba poistovjetiti s neučinkovitom opuštenošću u školi nego s poticajnim ozračjem za razvoj kreativnosti i stvaralaštva - što treba prihvatiti i drugdje kao obrazovni način koji se učenicima sviđa.

\section{LITERATURA}

1/ Tanja ALAČ, „Utjecaj okolinskih faktora na motivaciju učenika glazbene škole", Tonovi, 58 (2), Zagreb, 2011., 42-76.

2/ Robert C. BECK, Motivacija: teorija i načela, Jastrebarsko: Naklada Slap, 2003.

3/ Davor BRĐANOVIĆ, „Glazba u 21. stoljeću - između dokolice i kiča“, Nova prisutnost, 11 (1), Zagreb, 2013., 89-100.

4/ Davor BRĐANOVIĆ, „Glazbene preferencije učenika srednje glazbene škole“, Napredak: časopis za pedagogijsku teoriju i praksu, 155 (1-2), Zagreb, 2014., 47-64.

5/ Davor BRĐANOVIĆ, „,Glazbena darovitost i obrazovni sustav“, Školski vjesnik: časopis za pedagoška i školska pitanja, 64 (4), Split, 2015., 661-678.

6/ Davor BRĐANOVIĆ, Glazbene sposobnosti, osobine ličnosti i obilježja okoline kao prognostički pokazatelji razvoja glazbene kompetencije, Doktorska disertacija, Zagreb, Sveučilište u Zagrebu, Učiteljski fakultet, 2016.

7/ Davor BRĐANOVIĆ, „,Vrednovanje u glazbenom obrazovanju i obrazovna reforma: stavovi nastavnika glazbene škole prema godišnjem ispitu sviranja instrumenta", Napredak: časopis za pedagogijsku teoriju i praksu, 158 (3), Zagreb, 2017., 339 - 362. 
8/ Željko BURCAR, „Što roditelji očekuju od škole kada ih se pozove na suradnju“, Učenici, učitelji i roditelji zajedno na putu uspješnog odgoja i obrazovanja: suradnja, partnerstvo, međuljudski odnosi, međusobno povjerenje i poštovanje, suodgovornost, Zbornik radova 7. učiteljske škole održane 10. - 12. studenog 2005. godine u Lovranu, Hrvatski pedagoško književni zbor, gl. ur. Hrvoje VRGOČ, Zagreb, 2005., 118-122.

9/ Anita BUŠLJETA, „Globalizam - ideologija globalizacije“, Socijalna ekologija: časopis za ekološku misao i sociologijska istraživanja okoline, 19 (2), Zagreb, 2010., 127-149.

10/ Stjepan CIPEK, „Pedagoška važnost susreta u odgojno-obrazovnom procesu", Učenici, učitelji i roditelji zajedno na putu uspješnog odgoja i obrazovanja: suradnja, partnerstvo, međuljudski odnosi, međusobno povjerenje i poštovanje, suodgovornost, Zbornik radova 7. učiteljske škole održane 10. - 12. studenog 2005. godine u Lovranu, Hrvatski pedagoško književni zbor, gl. ur. Hrvoje VRGOČ, Zagreb, 2005., 95-106.

11/ Paola DI PIETRO, Kako preživjeti djetetovu školu, Rijeka: Izdavački centar Rijeka, 2009.

12/ William GLASSER, Kvalitetna škola: škola bez prisile, Zagreb, Educa, 1994.

13/ Ellen KEY, Stoljeće djeteta, Zagreb, Educa, 2000.

14/ Dejan LJUŠTINA, „Svijet i Hrvatska, trendovi koji će obilježiti 2017.“, Jutarnji list, 29. siječnja 2017., https://www.jutarnji.hr/vijesti/svijet/svijet-i-hrvatska-trendovi-koji-ce-obilj eziti-2017/556 2695/, 08.01.2018.

15/ Antun MIJATOVIĆ, „Usustavljivanje razvoja obrazovanja“, Društvena istraživanja, 5 (1) 21, Zagreb, 1996., 3-22.

16/ Boris PETZ (ur.), Ivan FURLAN, Slavko KLJAJIĆ, Vladimir KOLESARIĆ, Mirjana KRIZMANIĆ, Silvija SZABO i Branimir ŠVERKO, Psihologijski rječnik, Jastrebarsko, Naklada Slap, 2005.

17/ Nikola PASTUOVIĆ, Obrazovanje i razvoj: Kako obrazovanje razvija ljude i mijenja društvo, a kako društvo djeluje na obrazovanje, Zagreb, Institut za društvena istraživanja u Zagrebu i Učiteljski fakultet Sveučilišta u Zagrebu, 2012.

18/ Boris PETZ, Vladimir KOLESARIĆ i Dragutin IVANEC, Petzova statistika: Osnovne statističke metode za nematematičare, Jastrebarsko: Naklada Slap, 2012.

19/ Gordana POPOVIĆ, Susreti s učenicima u srednjim školama: priručnik za razrednike, Đakovo: Tempo, 2008.

20/ Metod RESMAN, „Timska kultura - oporba razrednoj kulturi“, Učenici, učitelji i roditelji zajedno na putu uspješnog odgoja i obrazovanja: suradnja, partnerstvo, međuljudski odnosi, međusobno povjerenje i poštovanje, suodgovornost, Zbornik radova 7. učiteljske škole održane 10. - 12. studenog 2005. 
godine u Lovranu, Hrvatski pedagoško književni zbor, gl. ur. Hrvoje VRGOČ, Zagreb, 2005., 13-35.

21/ Ken ROBINSON i Lou ARONICA, Element, Zagreb: V.B.Z. d.o.o., 2011.

22/ Robert ROSENTHAL i Lenore JACOBSON, "Pygmalion in the Classroom“, The Urban Review, 3 (1), Dordrecht, 1968., 16-20.

23/ Neven SESARDIĆ, „Fatamorgana obrazovne reforme“, Jutarnji list, 7. siječnja 2018., https://www. jutarnji.hr/vijesti/obrazovanje/fatamorgana-obrazovne-reforme-ugledni-hrvatski-filozof-propitkuje-dosege-ulaganja-u-unapredenje-skolskog-sustava/6906738/, 08.01.2018.

24/ Neven SESARDIĆ, „Zašto je, ipak, racionalno smanjiti očekivanja od obrazovne reforme?“, Jutarnji list, 20. siječnja 2018., https://www.jutarnji.hr/ magazin/zasto-je-ipak-racionalno-smanjiti-ocekivanja-od-obrazovne-reforme-ugledni-filozof-odgovara-na-kriti ke-koje-je-dobio-zbog-svoje-provokacije/6952269/, 21.01.2018.

25/ Louise STOLL i Dean FINK, Mijenjajmo naše škole: kako unaprijediti djelotvornost i kvalitetu škola, Zagreb: Educa, 2000.

26/ Slavica ŠıMIĆ ŠAŠıĆ, „Odnos nastavnik - učenik: sličnosti i razlike s obzirom na dob učenika te efekti na učenje“, Odnosi u školi: prilozi za pedagogiju odnosa, Monografija, Učiteljski fakultet Sveučilišta u Zagrebu, ur. Vesna BILIĆ i Slavica BAŠIĆ, Zagreb, 2016., 98-133.

27/ France VREG, „Globalizacija in elektronska demokracija: Politološko-sociološki vidiki razvoja informacijske družbe“, Teorija in praksa, 38 (1), Ljubljana, 2001., 5-28.

28/ Slavko VUČAK, „Prema školi koja uči: zajednici učenika, učitelja i roditelja“, Učenici, učitelji i roditelji zajedno na putu uspješnog odgoja i obrazovanja: suradnja, partnerstvo, međuljudski odnosi, međusobno povjerenje i poštovanje, suodgovornost, Zbornik radova 7. učiteljske škole održane 10. - 12. studenog 2005. godine u Lovranu, Hrvatski pedagoško književni zbor, gl. ur. Hrvoje VRGOČ, Zagreb, 2005., 37-49. 


\section{SAŽETAK \\ OČEKIVANJA UČENIKA OD OBRAZOVANJA U GLAZBENOJ ŠKOLI}

Glazbeno obrazovanje u glazbenoj školi sadrži optimalan odnos tradicionalnih i suvremenih pedagoških postupaka i dobar je primjer uspješnog suživota „starog" i „novog" u obrazovanju. Stalni izazov predstavlja mu propitivanje zahtjeva vremena u kojem se ostvaruje te planiranje nužnih obrazovnih prilagodbi. U tom smjeru ovaj je rad - nastao kao dio aktivnosti povodom obilježavanja 190 godina od početka rada Glazbene škole u Varaždinu - istražio današnja očekivanja učenika od obrazovanja u glazbenoj školi.

$\mathrm{U}$ istraživanju, koje je bilo dobrovoljno i anonimno, sudjelovala su 152 učenika Glazbene škole u Varaždinu. Obuhvaćen je uzorak u rasponu od prvog pripremnog razreda za srednju glazbenu školu do četvrtog razreda srednje glazbene škole. Korišten je instrument Upitnik glazbenih očekivanja konstruiran za ovo istraživanje.

T-testom za nezavisne uzorke nisu nađene statistički značajne razlike u očekivanjima prema glazbenom obrazovanju u glazbenoj školi s obzirom na spol ispitanika. Izuzetak predstavlja očekivanje zarade gdje učenici statistički značajno više od učenica $(t=3,81 ; p=0,000)$ procjenjuju kako uče glazbu jer ona omogućava dobru zaradu.

Kruskal-Wallisovim testom među konstruiranim su se grupama - 1. i 2. pripremni razred za srednju glazbenu školu $\left(G \breve{S}^{42}\right)$; 1. i 2. r. srednje GŠ; 3. i 4. r. srednje GŠ - pokazale statistički značajne razlike u procjenama očekivanja prema glazbenom obrazovanju kod tvrdnji: pohađam GŠ jer su me na to potakli roditelji (procjene $s$ uzrastom rastu), iznenadilo me što za GŠ treba redovito dosta vježbati sviranje/pjevanje (procjene s uzrastom padaju), idem u GŠ jer se želim profesionalno baviti glazbom (procjene $s$ uzrastom rastu), GŠ nije ispunila moja očekivanja (procjene s uzrastom rastu), učim glazbu jer ona omogućava dobru zaradu (procjene s uzrastom rastu), upisao/la sam GŠ jer svirati i pjevati nije teško (procjene s uzrastom padaju), GŠ treba nuditi više praktičnih glazbenih sadržaja (procjene s uzrastom rastu), u GŠ je premalo teorijskih glazbenih sadržaja (procjene s uzrastom rastu) i - u GŠ su mi najvažnije dobre ocjene (procjene $s$ uzrastom padaju).

Ukupni dobiveni rezultati - procjene na skalama upitnika i odgovori na pitanja upitnika otvorenog tipa - upućuju na zaključak kako glazbena škola ostvaruje glazbeno-obrazovna očekivanja svojih učenika.

42 GŠ - glazbena škola. 
Dobivene primjedbe i prijedlozi učenika pokazuju da oni tijekom srednjoškolskog glazbenog obrazovanja upoznaju samo dio obrazovnih i profesionalnih mogućnosti u glazbi. Stoga bi u budućem radu glazbena škola trebala ostvariti proširivanje njihovih vidika.

Ključne riječi: glazba; Glazbena škola u Varaždinu; glazbeno obrazovanje; učenici glazbe.

\section{SUMMARY}

\section{STUDENTS' EXPECTATIONS OF EDUCATION IN MUSIC SCHOOL}

Music education provided by music school has an optimal proportion of traditional and contemporary pedagogical methods, thus serving as a good example of successful coexistence of the "old" and the "new" in education. Its constant challenge is questioning the demands of time and planning necessary educational adjustments. This is the premise which this work focuses on and has come into being as part of the activities carried out to mark the $190^{\text {th }}$ anniversary of the founding of Varaždin Music School and exploring today's expectations of the education students receive in this school.

The research, which was voluntary and anonymous, involved 152 Varaždin Music School students. The sample included students in the first preparatory grade, and in Grades from 1 to 4 of the secondary music school. The questionnaire on expectations of music education designed for this research was used.

The t-test showed no statistically significant differences in the expectations of music education in the music school with respect to the sex of the respondents. An exception is the expectation of earnings, where the estimate of male students that they learn music because it creates the prospects for good earnings is statistically significantly higher than that of the female $(t=3.81, p=0.000)$ respondents.

Kruskal-Wallis's test amongst the constructed groups $-1^{\text {st }}$ and $2^{\text {nd }}$ grade of preparatory education for secondary music school $\left(\mathrm{MS}^{43}\right) ; 1^{\text {st }}$ and $2^{\text {nd }}$ grade of secondary MS; $3^{\text {rd }}$ and $4^{\text {th }}$ grade of secondary MS - showed statistically significant differences in the estimates of expectations of music education regarding the following statements: my parents motivated me to go to music school (estimates increase with age), I was surprised that for MS one has to regularly practice playing/singing (estimates decrease with age), I go to MS because I want to be

43 MS - music school. 
a professional musician (estimates increase with age), MS did not meet my expectations (estimates increase with age), I learn music because it allows good earnings (estimates increase with age), I enrolled in MS because playing and singing is not difficult (estimates decrease with age), MS should offer more practical music content (estimates increase with age), MS does not provide enough theoretical music content (estimates increase with age), the most important in MS is to achieve good marks (estimates decrease with age).

The overall results obtained - estimates on the questionnaire scales and answers to open type questions - point to a conclusion that music school fulfils musical and educational expectations of its students.

The comments and suggestions given by students show that during secondary music education they become aware of only part of educational and professional opportunities in music. Therefore, in the future, music school should work on broadening their perspective.

Key Words: music; Varaždin Music School; music education; music students. 
